\title{
LANGUAGE PROGNOSIS AND LANGUAGE DIVERSITY IN THE RUSSIAN FEDERATION: SOCIOLINGUISTIC ASPECT
}

\author{
Aysa N. Bitkeeva \\ Institute of Linguistics of Russian Academy of Sciences, Moscow, Russia; \\ Moscow State Pedagogical University, Moscow, Russia \\ Monika Wingender \\ Justus Liebig University Giessen, Giessen, Germany \\ Vida Yu. Mikhalchenko \\ Institute of Linguistics of Russian Academy of Sciences, Moscow, Russia
}

\begin{abstract}
The article considers the methodological basis of sociolinguistic research into language perspectives with a focus on linguistic diversity in the Russian Federation, the study of which is closely connected with such sociolinguistic concepts as language situation, language policy and language planning. Over the recent decades, sociolinguistics has witnessed a real boom in new research showing a growing variety of methods for studying linguistic diversity. Closer consideration of these papers shows that the authors focus on the search for tools to analyze the prerequisites, history and current situation of linguistic diversity. However, research methods for the future development of linguistic diversity linguistic forecasting, lack for scientific representation. Analysis of the prospects for the development of languages in present-day conditions is no less relevant research topic. The identification of the laws of language development requires a comprehensive approach from the position of sociolinguistics, which leads to the multifaceted nature of scientific research, 2 the consideration of the object not only from the linguistic point of view, but also from sociolinguistic, psycholinguistic, $\underset{2}{2}$ ethnolinguistic etc. factors. The authors present an overview of sociolinguistic methods. As part of a combination of of methods, which is justified by the variety of goals and subjects of linguistic forecasting, the authors analyze some possible

Key words: sociolinguistic methods, language perspectives, language situation, language policy, language planning.

Citation. Bitkeeva A.N., Wingender M., Mikhalchenko V.Yu. Language Prognosis and Language Diversity in the Russian Federation: Sociolinguistic Aspect. Vestnik Volgogradskogo gosudarstvennogo universiteta. Seriya 2. Yazykoznanie [Science Journal of Volgograd State University. Linguistics], 2019, vol. 18, no. 3, pp. 6-23. (in Russian). DOI: https://doi.org/10.15688/jvolsu2.2019.3.1

\section{ПРОГНОЗИРОВАНИЕ И ЯЗЫКОВОЕ МНОГООБРАЗИЕ В РОССИЙСКОЙ ФЕДЕРАЦИИ: СОЦИОЛИНГВИСТИЧЕСКИЙ АСПЕКТ}

\author{
Айса Николаевна Биткеева \\ Институт языкознания РАН, г. Москва, Россия; \\ Московский педагогический государственный университет, г. Москва, Россия
}




\section{Моника Вингендер}

Гиссенский университет им. Юстуса Либига, г. Гиссен, Германия

\section{Вида Юозовна Михальченко}

Институт языкознания РАН, г. Москва, Россия

Аннотация. В статье рассматриваются методологические основы социолингвистического прогнозирования с акцентом на анализе языкового многообразия в Российской Федерации, исследование которого тесно связано с такими социолингвистическими понятиями, как «языковая ситуация», «языковая политика» и «языковое планирование». Показывается, что в последние десятилетия наблюдается увеличение публикаций по проблемам социолингвистики, демонстрирующих расширение набора методов изучения языкового многообразия и отражающих поиск инструментов анализа его предпосылок, истории и актуального состояния. Констатируется отсутствие работ, посвященных методам лингвистического прогнозирования. Утверждается актуальность осмысления перспектив развития языков в современных условиях и необходимость комплексного подхода при выявлении закономерностей данного процесса, который определяет многоаспектность научного исследования, рассмотрение объекта не только с собственно лингвистической точки зрения, но и с учетом социо-, психо- и этнолингвистических факторов. В статье приводится обзор социолингвистических методов. В рамках комбинирования методов, которое обусловлено сложностью целей и разнообразием предметов лингвистического прогнозирования, охарактеризованы некоторые из его методов (параметрический, статистический, дискурсивный) и их практическое применение при изучении языкового многообразия. Выдвигаются прогнозы относительно языкового многообразия в Российской Федерации.

Ключевые слова: социолингвистические методы, перспективы развития языков, языковая ситуация, языковая политика, языковое планирование.

Цитирование. Биткеева А. Н., Вингендер М., Михальченко В. Ю. Прогнозирование и языковое многообразие в Российской Федерации: социолингвистический аспект // Вестник Волгоградского государственного университета. Серия 2, Языкознание. -2019. - Т. 18, № 3. - С. 6-23. - DOI: https://doi.org/10.15688/jvolsu2.2019.3.1

\section{Введение}

В последние десятилетия для лингвистики особенно актуальной стала тема развития методов, теорий и подходов в междисциплинарном аспекте. Так, в социолингвистике наблюдается настоящий бум новых исследований, демонстрирующих растущее многообразие методов. Большое количество работ появилось в англоязычном научном пространстве (см.: [Discursive Approaches..., 2016; Research Methods..., 2015; The Oxford Handbook..., 2018; The Routledge Handbook..., 2018]); в отечественной науке о языке также уделяется особое внимание развитию методологической базы, расширению аспектов социолингвистических исследований (см., например: [Национальные языки в эпоху глобализации..., 2012; Язык и общество, 2016; Языковая политика..., 2016; и др.]). Такие работы освещают динамику развития социолингвистики как науки, подчеркивают ее междисциплинарный статус.

В данной статье сделан акцент на анализе языкового многообразия в Российской Федерации, исследование которого тесно свя- зано с такими социолингвистическими понятиями, как «языковая ситуация», «языковая политика» и «языковое планирование». При ближайшем рассмотрении названных отечественных и зарубежных сборников статей становится ясно, что их авторы фокусируются на поиске инструментов анализа предпосылок, истории и актуальной ситуации языкового многообразия. Однако удивляет тот факт, что в этих изданиях нет материалов, посвященных методам изучения перспектив, то есть будущего развития языкового многообразия - лингвистического прогнозирования, хотя касающаяся его тема в социолингвистических работах затрагивалась, например, в советский период. Так, Л.Б. Никольский в 1970 г. отмечал, что связь между прогнозированием и языковым планированием очевидна, так как последнее имплицирует прогнозы дальнейшего развития языков [Никольский, 1970, с. 12-13]. Что касается конкретных методов лингвистического прогнозирования, то при их разработке исследователи сталкиваются с определенными проблемами, очевидно обусловленными гетерогенностью целей и множествен- 
ностью областей прогнозирования, требующих применения комплекса различных методов. Ввиду этого, думается, необходимо комбинирование разных методов (в соответствии с mixed methods approach), которое будет способствовать прогнозированию развития языкового многообразия. Прежде чем подробнее обсудить проблемы прогнозирования в социолингвистике, представим обзор социолингвистических методов, включающий сбор материала и его интерпретацию, что позволит показать актуальность целей, предмета и методов лингвистического прогнозирования. Согласно методике mixed methods approach охарактеризуем параметрический, статистический и дискурсивный методы и продемонстрируем возможности их применения при исследовании языкового многообразия, в качестве выводов предложим прогнозы относительно языкового многообразия в Российской Федерации.

\section{Обзор методов в социолингвистике}

Социолингвистические методы можно разделить на две большие группы: 1) методы сбора материала и 2) методы его интерпретации. К первой группе относятся анкетирование, наблюдение, интервьюирование, тестирование, анализ письменных источников и др., ко второй группе - количественные и качественные методы. Для обработки материала чаще всего используются разновидности корреляционного анализа, который применяется для изучения взаимосвязей между социальными и языковыми переменными величинами. Выбор методов и их сочетание зависят от специфики рассматриваемой проблемы. Так, при исследовании латентных явлений влияния родного языка на речь билингва на функционально втором языке можно объединить анкетирование с методами экспериментальной фонетики; формирования двуязычия - применить анкетирование и записи речи (или письменные тесты); качества письменной речи - опрос и анализ письменных источников билингва, связанный с поисками индекса качества речи. Все указанные сочетания разных методов и приемов были реализованы в социолингвистических работах 1980-2000-х гг.: [Аюпова, 1988; Дырхеева, 2002; Биткеева, 2006; Мето- ды..., 1976; Михальченко, 1984; 2014; 2018; и др.]. Отметим, что для их успешного объединения, обеспечивающего убедительный, достоверный результат, необходимо следить за возможностью такого их использования, при котором данные, полученные одним методом, контролировались бы данными, полученными посредством другого, например, субъективные данные (самооценки) о знании функционально второго языка уточняются объективными - анализом устных и письменных тестов. Это взаимодействие методов наблюдается при изучении качества речи: самооценка и объективная оценка практических знаний билингва исследователем.

В последние десятилетия отечественная социолингвистика пополнилась новыми приемами и методами сбора и интерпретации материала: появилась потребность в методах анализа с применением компьютерных технологий, обращении к методам смежных наук. Так, политологи, экономисты создают программы мониторинга политической, экономической ситуации в мире, системы антикризисного реагирования на внутриполитические, международные конфликты, модели прогнозирования изменения политической ситуации в мире в ближайшие десятилетия [Ахременко, 2006; Барановский, Владиславлева, 2002; Бородкин, 2016; и др.]. Анализ перспектив развития языков в современных условиях не менее актуальная тема. Выявление закономерностей развития языков требует от социолингвистики комплексного подхода, что обусловливает многоаспектность научного исследования, рассмотрение объекта не только с собственно лингвистической точки зрения, но и с учетом социо-, психо- и этнолингвистических факторов.

В современной социолингвистике активно используются достижения мировых технологий: создаются информационные базы данных языков, программы мониторинга языковой ситуации в регионах мира, системы антикризисного реагирования на внутриполитические, международные и языковые конфликты, модели прогнозирования изменений политической ситуации, языковой ситуации в мире на отдаленный во времени период. Это помогает систематизировать материал, расширять фактологическую базу исследований, выво- 
дить их на более высокий уровень, решать важные задачи лингвистической науки.

Так, в диахронической социолингвистике стали применять метод реинтерпретации данных разных наук для выяснения социолингвистических истин. Исследователи шире используют прием изучения языковых биографий информантов для выявления динамики речевой практики разных поколений. Важным приемом сбора материала и интерпретации условий развития социальных функций языка можно считать составление социолингвистического портрета языка, а для определения социального статуса информантов - поиск маркеров индивидуальной речи.

Существуют программы, с помощью которых проводится текстологический анализ, например, на частотность эмоционально окрашенных слов и выражений, позволяющий сделать вывод о позиции общества по тому или иному актуальному вопросу. Эти частотные единицы можно квалифицировать как социолингвистические маркеры.

Комплексный подход представляет картину возможных сценариев развития языка. Например, анализ языка электронной коммуникации может дополнить и уточнить исследование, посвященное выявлению имплицитной информации. Поскольку политика и идеология неизбежно влияют на общественное политическое сознание общества, объективные данные возможно получить в результате изучения материалов социальных сетей, но не публикаций СМИ, которым характерна определенная предсказуемость.

\section{Прогнозирование в социолингвистике}

Опираясь на описанные методы сбора материала и его интерпретации, а также вышеупомянутое их комбинирование, обратимся к основам прогнозирования в социолингвистике.

Как уже говорилось ранее, связь языкового планирования с прогнозированием была актуальной темой уже в советском языкознании. Прогнозирование находится в исследовательском поле проспективной социолингвистики, занимающейся проблемами планирования и прогнозирования языкового развития в прикладном контексте. Очевидно, прикладные исследования теснее связаны с текущими политическими процессами, направлены на разрешение текущих проблемных ситуаций в предельно сжатые сроки. Так, А.Д. Швейцер писал о том, что принципы планирования и прогнозирования широко использовались в процессе языкового строительства в СССР, и отмечал, что языковое планирование должно опираться на научное прогнозирование [Швейцер, 1977, с. 154]. Ю.Д. Дешериев выделял пять областей прогнозирования, которые представлены в «Словаре социолингвистических терминов», где оно толкуется как «исследование конкретных перспектив развития как отдельного языка, его внутренней структуры, так и языковой ситуации в той или иной социальной общности. К этим областям относятся:

1) развитие языков в мире;

2) судьба отдельных языков; языков;

3) развитие общественных функций

4) структурное развитие языков;

5) развитие и взаимодействие языков» [Словарь социолингвистических терминов, 2006, с. 271].

Если рассматривать это определение в контексте многообразия предмета социолингвистики, становится понятной сложность точной формулировки целей этого направления исследований, поскольку очевидно и их многообразие. Итак, наряду с оценкой перспектив исчезающих языков лингвистическое прогнозирование преследует (или должно) такие цели:

- описание количественного и качественного развития языковых ситуаций;

- предсказание и предотвращение этнолингвистических конфликтов;

- прогнозирование хода nation-building и его влияние на развитие языкового многообразия в многонациональных обществах.

Однако и этого недостаточно для исчерпывающего исследования языкового многообразия, поскольку в целом необходимо выяснить, каковы же масштабы прогнозирования: 1) предсказание хода развития языков и языковых сообществ, основанное на данных или/и 2) разработка рекомендаций для правительства, политики, общества и др. Оперативное использование прогнозной информа- 
ции способно сократить время на выработку решения, повысить результативность, не допустить возникновения вероятной проблемы или ослабить ее.

В рамках статьи мы вынуждены ограничиться лингвопрогнозом хода языкового развития, основанном на синхронных данных. Предлагаем комбинирование методов (параметрического, статистического и дискурсивного), обусловленное многообразием целей и предмета лингвистического прогнозирования.

\section{Лингвопрогноз:}

\section{методы и их реализация}

Традиционные методы прогнозирования включают подробное обследование разных языковых общностей, изучение способов организации их языковой жизни, речевой практики, а также оценку приверженности родному языку и готовности приложить усилия для поддержки своего языка в разных этнолингвистических условиях.

Одним из таких методов является $\boldsymbol{n a -}$ раметрический анализ - комплексное исследование факторов, влияющих на степень витальности языков, корреляционный анализ которых представляет прогностическую картину развития языковых общностей.

За основу анализа берутся основные параметры витальности языка: 1) демографическая мощность; 2) тип расселения, степень компактности проживания этнической группы; 3) коммуникативная мощность языка; 4) языковая компетенция, символическая мощность языка; 5) конфессиональные характеристики этнической группы и т. д.

Комплексный анализ указанных параметров представляет прогностическую картину развития языковых общностей. В разных языках она разная: фиксируется как положительная, так и отрицательная динамика.

При оценке жизнеспособности языков, которая измеряется широтой и интенсивностью их применения в социально значимых сферах общения, важным показателем становится демографическая мощность [Словарь социолингвистических терминов, 2006, с. 97], соотношение количества владеющих им с количеством членов соответствующей этнической группы.
Перепись населения 2010 г. свидетельствует о том, что в Российской Федерации проживают носители 275 языков. Коренные мажоритарные народы представлены 30 языковыми общностями, коренные миноритарные народы 62 , а этнические меньшинства - 45-50. В перечень включены все носители того или иного языка вплоть до единичных представителей народа. Для социолингвистической оценки важны не общие подсчеты этносов, а анализ языковых общностей. Большинству народов России свойственно увеличение этнической общности, представляющей собой базовую языковую общность (от 1 до $18 \%$ ). У некоторых народов этническая общность уменьшается, например: русские (-4 \%), адыгейцы (-1 \%), башкиры (-4 \%), кабардинцы (-2 \%), карелы (-31\%), коми (-21\%), марийцы (-7\%), удмурты (-11\%), чуваши (-8 \%). Обычно в таком случае наблюдается потеря параметров языковой общности: адыгейцы (-1 \%), кабардинцы (-3 \%), карелы (-64 \%), коми (-35\%), марийцы (-16\%), удмурты (-24\%), чуваши (-20\%). Тревожным для функционального развития языков является показатель потери языка представителями народа. Здесь исключение представляют народы, у которых увеличивается процент знающих этнический язык: черкесы (-4 \%), карачаевцы (-10\%), лезгины (-2\%), чеченцы (-19\%).

В условиях, когда доля титульного народа в населении региона невелика, функциональное развитие языка сталкивается с трудностями. Демографическое неравновесие приводит, в частности, к тому, что русский язык доминирует, им владеет подавляющее большинство населения, некоторые жители считают его родным языком, и их количество постоянно растет. Так, по переписи 2010 г. признают русский родным 18,2 \% титульного населения Мордовии, 20,2 \% марийцев в Марий Эл, 34,9 \% удмуртов в Удмуртской Республике, 5 \% татар в Республике Татарстан, 7,7\% башкир в Республике Башкортостан (Итоги Всероссийской переписи населения..., с. 272). Владение же русским языком во всех республиках достигает 80-90\%.

Значимым параметром успешного функционирования языка является способ расселения языковой общности. Если этнической общности характерно дисперсное расселение 
и малочисленность, ассимиляционные процессы протекают быстро. Языки таких общностей становятся функционально неравнозначными доминирующему языку, менее престижными. Крупные этнические группы, которых отличает компактный тип проживания, как правило, менее подвержены влиянию доминирующей языковой социальной среды на этническую группу, ее язык; ассимиляция отступает, и сохраняется этноязыковое своеобразие группы. Это касается и молодого поколения, наиболее активной и динамичной части этнической группы.

К компактному типу расселения склонны этносы, у которых сохранились традиции большой семьи. Немаловажную роль играют и конфессиональные характеристики этнической группы. Для республик Российской Федерации более характерен сельский способ расселения титульных наций, который связан с более низким уровнем образования и более высоким уровнем языковой компетенции на родном языке, чем у горожан. В городах чаще всего преобладает русское или русскоязычное население, а представители титульных наций подвержены сильной языковой ассимиляции.

В оценке витальности языка значима его символическая мошность. Язык играет важную роль в менталитете народа, поскольку менталитет народа как социоэтнической группы представляет собой совокупность образа мыслей, символов, духовных и морально-этических установок. Это регулятор жизнеспособности данной языковой общности. В последние годы в российском научном сообществе идут дискуссии по поводу нового толкования понятия «родной язык». Предпосылкой послужил тот факт, что некоторые представители ранее однородной в языковом и культурном плане общности не признают родным языком «свой» язык, а пользуются в повседневной жизни «чужим», и таким образом меняется их этническая идентичность. Действительно, встречается «языковой нигилизм» определенной части титульных народов ряда республик, обнаруживающийся в нежелании знать свой язык из-за его «социальной непрестижности». Отметим, что в кавказских республиках это негативное явление выражено гораздо слабее. Однако, как показывают поле- вые исследования, все же для большинства народов Российской Федерации понятие «родной язык» неразрывно связано с понятием языка своего народа, независимо от степени владения им. Родной язык служит одним из основных признаков этнической принадлежности человека, важным этническим символом. О болезненности этой темы свидетельствую активные в течение 2018 г. дебаты на федеральном и региональных уровнях о добровольном изучении национальных языков в школе.

Коммуникативная мощуность определяется количеством социальных функций языка. Сегодня в Российской Федерации только русский язык в полной мере реализует свои функции и, оставаясь при этом единственным языком межнационального общения в стране, выполняет государствообразующую, консолидирующую роль. Русский язык преподается на всех уровнях образовательной системы, его доминирующее положение объясняется статусом государственного языка Российской Федерации, а также тем, что владение им способствует поступлению в высшие учебные заведения России, возможности получения престижной профессии, мобильности в пределах страны и т. д. Часто региональные языки республик, провозглашенные государственными языками, не обладают, например, достаточно развитыми функциональными стилями, не в состоянии выполнять те или иные общественные функции.

По данным Министерства образования и науки РФ за 2015/16 учебный год, обучение проходило всего на 5 языках многочисленных коренных народов России: с 1-го по 4-й класс на крымско-татарском, мордовском эрзя и чувашском, с 1-го по 11-й класс - на башкирском и татарском. Несколько лучше обстояло дело с обучением на языках в сельской местности. В селах обучение шло на 12 языках: с 1-го по 4-й класс - на аварском, мордовском мокша, осетинском, удмуртском и чеченском, с 1-го по 9-й класс - на марийском луговом, с 1-го по 11-й класс - на башкирском, даргинском, крымско-татарском, мордовском эрзя, татарском, чувашском (Данные Министерства науки и образования РФ). Отметим, что обучение на языке вовсе не означает, что все предметы школьного цикла преподаются на нем, чаще всего обучение проводится в 
рамках таких дисциплин, как язык и литература. В подавляющем большинстве школ в республиках родной язык коренного населения изучается как предмет, практически иностранный язык, с недостаточным количеством часов, отведенных на его освоение.

В сфере СМИ на региональных государственных языках в разных республиках также складываются разные ситуации, например, периодика отличается количеством выпускаемых номеров и объемом тиража. По данным Российской книжной палаты за 2016 г., самое большое количество газет выходило на татарском языке - 176 наименований, башкирском - 71, чувашском - 44, аварском - 22, чеченском - 21, осетинском - 15, марийских языках -14 , удмуртском - 13, лезгинском -9 , даргинском - 8. Меньше всего газет издавалось на калмыцком и коми - 5 наименований, крымско-татарском - 4, ингушском, мордовских эрзянском и мокшанском - по 3 наименования, адыгейском - 2 (Российская книжная палата).

В сфере радио и телевидения ситуации примерно одинаковые: большая часть эфирного времени отдана русскоязычным передачам, на национальных языках в основном транслируются новости, программы, посвященные национальной культуре.

Языки, объявленные государственными, почти не используются в важнейших официальных сферах - административном управлении, делопроизводстве и др. За титульными языками законодательно не закреплено обязательное их употребление в главных официальных сферах, что допускает расплывчатые формулировки. Так, в законе Республики Мордовия использование мордовского языка (мокшанского или эрзянского) в области делопроизводства, судопроизводства, государственных органах, организациях и предприятиях, а также на этикетках и в номенклатурных списках товаров, производимых в Мордовии, допускается «при необходимости» (Закон Республики Мордовия, III, ст. 11, IV, ст. 17, 20). Такая формулировка фактически означает, что можно не пользоваться языком, оправдываясь тем, что необходимости не было.

Одна из положительных тенденций функционального развития миноритарных языков
Российской Федерации в том, что малые языки активно функционируют в сфере информационных технологий, находят свою аудиторию. Об этом говорилось в аналитических обзорах исследователей на лингвистическом форуме, прошедшем в Институте языкознания РАН в апреле 2019 года.

Перспективы развития языка зависят и от конфессионального фактора. Отметим, что у мусульманских народов, для которых характерны традиции большой семьи, компактное расселение, часто отмечается более высокий уровень знания родного языка, этнической интеграции и т. д.

Таким образом, для выявления специфики языковой жизни разных общностей необходимо провести некоторые процедуры социолингвистического характера:

- проследить тенденции развития исследуемых языковых общностей за 2-3 десятилетия: определить увеличение или уменьшение количества их членов и последовательность / прерывистость этих процессов (по данным переписи населения);

- выявить отношение к языку среди исследуемых сообществ: знание языка (по данным переписи населения);

- дать оценку объективных возможностей применения своего языка в разных сфеpax общения: наличие радио- и телепередач на исследуемом языке (конкретные социолингвистические исследования);

- изучить реальное функционирование исследуемого языка как в конкретных языковых общностях, так и у отдельных носителей (конкретные социолингвистические исследования).

Получив с использованием перечисленных процедур данные о языковой общности, можно перейти к прогнозированию ее развития: предположить возможность развития положительного или отрицательного функционального сдвига в рассматриваемом языке.

В обобщенном виде языковое развитие в России можно представить следующим образом:

- если в течение 2-3 десятилетий удерживается прежнее количество членов языковой общности или же оно увеличивается, то вполне возможно дальнейшее сохранение и увеличение данной языковой общности; 
- если количество членов языковой общности уменьшается постепенно или иногда при одноразовом частичном увеличении, то возможна борьба тенденций к сокращению или же расширению языковой общности; результат такой конкуренции зависит от соотношения витальности языка и силы давления этнолингвистических условий;

- если количество членов языковой общности постоянно уменьшается, можно прогнозировать последовательное исчезновение данного сообщества, его культуры и языка; в этом случае необходимо торопиться исследовать язык, записать его звучание, описать структуру, так как любой язык - итог человеческого творчества, часть богатства культуры всего человечества и он должен остаться навсегда в мировой сокровищнице языков и культур.

Проиллюстрируем сказанное данными, представленными в таблице.

Из таблицы видно, что в подавляющем большинстве случаев 1) каждые 10 лет уменьшается базовая этническая общность и 2) в связи с этим (кроме арчинского языка) снижается количество знающих язык соответствующего языкового сообщества. Эти две тенденции вызывают предположение об их продолжении в будущем.

Указанные тенденции позволяют прогнозировать продолжение процесса выхода из области активного функционирования названных языков малочисленных народов России. Несколько иное состояние обнаруживают остальные языки Российской Федерации (численностью носителей более 50 000). Прежде всего это сворачивание социальных функций языка, что проявляется в его замене в тех или иных сферах общегосударственным или местным государственным языком и свидетельствует об отрицательном языковом сдвиге.

Совокупность языковых общностей России с прогностической точки зрения можно описать по 4 моделям:

1. Стабильный тип развития языка (русский язык и др.).

2. Перспективный тип развития языка (чеченский, татарский и др.).

3. Нестабильный тип развития языка (большинство языков РФ).
4. Слабо перспективный тип развития языка (миноритарные языки, языки диаспор и др.) [Биткеева, 2018].

Тенденции в развитии языкового многообразия в России показывают, что требуется дальнейшая разработка методов прогнозирования, позволяющих не только анализировать актуальное развитие языков, но и предложить инструменты для этого.

В прогнозировании при выявлении языкового конфликта может быть использован статистический метод. Он направлен на определение социального напряжения по языковым вопросам. Определить его - значит найти меру влияния отдельных закономерностей и причин на развитие проблемы. В социологии существует ряд методов установления уровня социальной напряженности. Она измеряется в основном посредством тестов, позволяющих определить степень удовлетворенности респондентов реализацией их потребностей. Однако, как отмечают исследователи, опросные методы дают возможность получить информацию о состоянии общественного мнения, но не предоставляют инструментов для своевременного регулирования уровня напряжения, предупреждения дестабилизирующих общество социальных конфликтов. Очевидна необходимость комбинирования методов установления факторов, детерминирующих напряженность, определения социальных групп с высоким уровнем неудовлетворенности, предвидения форм ее проявления, степени воздействия на дестабилизацию развития и укрепления общества [Баранова, Фролов, 2012, с. 51-65].

Охарактеризуем подробно применяемый социологами метод построения моделей развития и реализации социального конфликта. Посредством этого метода устанавливаются соответствия между стадиями развития напряженности (качественная характеристика), ее уровнями (количественная характеристика) и формами проявления, влияющими на стабильность общества. Уровни развития напряженности зависят от неудовлетворенности населения, несоответствия между его предпочтениями, потребностями и реальным положением дел. Выделяются следующие уровни такого несоответствия: латентный (фоновый), повышенный, высокий, критический. 
Языки малочисленных (миноритарных) народов

\begin{tabular}{|c|c|c|c|c|c|}
\hline Национальность & $\begin{array}{c}\text { Численность } \\
\text { народа, } \\
2010 \text { г. }\end{array}$ & $\begin{array}{c}\text { Динамика } \\
\text { численности } \\
\text { народа, } \\
\text { с 2002- } \\
2010 \text { гг. }\end{array}$ & $\begin{array}{c}\text { Родной язык } \\
\text { данного народа }\end{array}$ & $\begin{array}{c}\text { Численность } \\
\text { знающих } \\
\text { данный язык } \\
\text { в РФ, } \\
2010 \text { г. }\end{array}$ & $\begin{array}{c}\text { Динамика } \\
\text { численности } \\
\text { знающих } \\
\text { данный язык в } \\
\text { РФ, с } 2002- \\
2010 \text { гг. }\end{array}$ \\
\hline Абазины & 43341 & $+14,23 \%$ & Абазинский & 37831 & $-1,09 \%$ \\
\hline Алеуты & 482 & $-10,74 \%$ & Алеутский & 45 & $-74,29 \%$ \\
\hline Андийцы & 11780 & $-45,98 \%$ & Андийский & 5800 & $-75,56 \%$ \\
\hline Арчинцы & 12 & $-86,52 \%$ & Арчинский & 970 & $+85,11 \%$ \\
\hline Ахвазцы & 7930 & $+24,37 \%$ & Ахвахский & 270 & $-96,37 \%$ \\
\hline Бежтинцы & 5958 & $-3,87 \%$ & Бежтинский & 6072 & $-6,02 \%$ \\
\hline Вепсы & 5936 & $-27,96 \%$ & Вепский & 3613 & $-37,20 \%$ \\
\hline Водь & 64 & $-12,33 \%$ & Водский & 68 & $-91,21 \%$ \\
\hline Годоберинцы & 427 & $-27,96 \%$ & Годоберинский & 128 & $+24,27 \%$ \\
\hline Гунзибцы & 918 & $-8,02 \%$ & Гунзибский & 1012 & $-44,97 \%$ \\
\hline Долганы & 7885 & $+8,59 \%$ & Долганский & 1054 & $-78,34 \%$ \\
\hline Ижорцы & 266 & $-18,65 \%$ & Ижорский & 123 & $-66,02 \%$ \\
\hline Ительмены & 3193 & $+0,41 \%$ & Ительменский & 82 & $-78,70 \%$ \\
\hline Каратинцы & 4787 & $-20,90 \%$ & Каратинский & 255 & $-96,12 \%$ \\
\hline Кереки & 4 & $-50,00 \%$ & Керекский & 10 & $-33,33 \%$ \\
\hline Кеты & 1219 & $-18,41 \%$ & Кетский & 213 & $-56,08 \%$ \\
\hline Коряки & 7953 & $-9,04 \%$ & Корякский & 1665 & $-44,85 \%$ \\
\hline Манси & 12269 & $7,32 \%$ & Мансийский & 938 & $-65,84 \%$ \\
\hline Нанайцы & 12003 & $-1,29 \%$ & Нанайский & 1347 & $-65,34 \%$ \\
\hline Нганасаны & 862 & $+3,36 \%$ & Нганасанский & 125 & $-75,25 \%$ \\
\hline Ненцы & 44640 & $+8,08 \%$ & $\begin{array}{l}\text { Ненецкий } \\
\text { тундровый } \\
\text { и лесной }\end{array}$ & 21926 & $-29,97 \%$ \\
\hline Нивхи & 4652 & $-9,88 \%$ & Нивхский & 1347 & $+95,78 \%$ \\
\hline Ороки & 295 & $-14,74 \%$ & Орокский & 47 & $-26,56 \%$ \\
\hline Орочи & 596 & $-13,12 \%$ & Орочский & 8 & $-96,89 \%$ \\
\hline Рутульцы & 35240 & $+17,75 \%$ & Рутульский & 30360 & $+3,33 \%$ \\
\hline Саамы & 1771 & $-11,05 \%$ & Саамский & 353 & $-55,15 \%$ \\
\hline Таты & 1585 & $-31,18 \%$ & Татский & 2012 & $-33,29 \%$ \\
\hline Телеуты & 2643 & $-0,26 \%$ & Телеутский & 975 & $-48,47 \%$ \\
\hline Тофалары & 762 & $-8,96 \%$ & Тофаларский & 93 & $-75,40 \%$ \\
\hline Тубалары & 1965 & $+11,33 \%$ & Тубаларский & 229 & $-47,48 \%$ \\
\hline Удэгейцы & 1496 & $-9,72 \%$ & Удэгейский & 103 & $-54,63 \%$ \\
\hline Ульчи & 2765 & $-5,08 \%$ & Ульчский & 154 & $-78,96 \%$ \\
\hline Ханты & 30943 & $+7,90 \%$ & Хантыйский & 9584 & $-29,36 \%$ \\
\hline Цахуры & 12769 & $+23,18 \%$ & Цахурский & 10596 & $+8,44 \%$ \\
\hline Цезы & 11683 & $-100,00 \%$ & Цезский & 12467 & $-18,81 \%$ \\
\hline Чамалинцы & 24 & $+100,00 \%$ & Чамалинский & 500 & $-78,77 \%$ \\
\hline Челканцы & 1181 & $+38,13 \%$ & Челканский & 310 & $-42,49 \%$ \\
\hline Чукчи & 15908 & $+0,89 \%$ & Чукотский & 5095 & $-34,19 \%$ \\
\hline Чулымцы & 355 & $-45,88 \%$ & Чулымский & 44 & $-83,70 \%$ \\
\hline Шорцы & 12888 & $-7,78 \%$ & Шорский & 2839 & $-54,28 \%$ \\
\hline Эвенки & 37843 & $+6,52 \%$ & Эвенкийский & 4802 & $-36,68 \%$ \\
\hline Эвены & 22383 & $+17,37 \%$ & Эвенский & 5656 & $-21,09 \%$ \\
\hline Энцы & 227 & $-4,22 \%$ & Энецкий & 43 & $-63,87 \%$ \\
\hline Юги & 1 & $-94,74 \%$ & Югский & 1 & $-99,24 \%$ \\
\hline Юкагиры & 1603 & $+6,23 \%$ & Юкагирский & 370 & $-38,74 \%$ \\
\hline
\end{tabular}

Примечание. В таблице приводятся не все языки коренных малочисленных народов России, так как, с одной стороны, по некоторым языкам данные переписи отсутствуют, а с другой - некоторые данные непонятны или не вызывают доверия, например, багвалинцы - 5 человек, а знающие этнический язык - 1447 (?!). 
Латентный (фоновый) уровень характеризуется относительной сбалансированностью условий и требований. При опросе респондентов такое состояние выражается в нейтральной оценке ситуации. Это не означает отсутствия проблемы, проявляется конструктивная социальная активность населения, выражающаяся в устных письменных обращениях граждан в местные органы управления с пожеланиями и требованиями уладить ситуацию.

Повышенный уровень социального напряжения выражает явное несоответствие между ожиданиями, потребностями и реальным положением дел; он характеризуется ростом обеспокоенности ситуацией, распространением тревоги относительно потенциальных угроз, недоверием властям. Проявляются признаки готовности противостоять нежелательным изменениям. Возможно проведение мирных акций, митингов, при этом адресат требований - местные власти.

Высокий уровень социальной напряженности связан с ростом неудовлетворенности, осознанием ситуации, реально угрожающей интересам субъектов. Формы проявления очевидны через обострение проблемных ситуаций, характерно формирование образа врага, проведение многочисленных митингов. Адресат требований - региональные власти.

Уровень языкового конфликта характеризуется завершением осознания обществом глубокого несоответствия социальнополитической ситуации его ценностям и интересам, обострением недовольства, которое приобретает массовый характер. Протестующие, как правило, обращают претензии в высокие (федеральные) властные структуры [Баранова, Фролов, 2012, с. 52].

Для измерения напряженности используются опросные методы, позволяющие зафиксировать текущие мнения, актуальные в социуме. Опросные листы строятся по методу шкалирования степени значимости факторов для информантов и неудовлетворенности положением дел по предложенным параметрам. Шкала важности в анкете - порядковая шкала с указанием границ от 1 до 6: 1. Совсем не важно. 2. Практически не важно. 3. Скорее не важно, чем важно. 4. Скорее важ- но, чем не важно. 5. Важно. 6. Очень важно. Шкала неудовлетворенности демонстрирует показатель социальной напряженности: 1. Полностью удовлетворен. 2. Практически удовлетворен. 3. Скорее удовлетворен, чем не удовлетворен. 4. Скорее не удовлетворен, чем удовлетворен. 5. Практически не удовлетворен. 6. Полностью не удовлетворен.

Прогностическая модель социальной напряженности выстраивается динамическим рядом развития показателя индекса социальной напряженности. Прогнозирование напряженности с целью определения возможных путей и средств ее снижения должно ответить на два вопроса: какого уровня социальной напряженности можно ожидать в будущем? какие условия и каким образом нужно изменить, чтобы достичь нейтрализации уровня социальной напряженности?

Описанная модель применима и к анализу языковых конфликтов. В качестве примера рассмотрим актуальную для России проблему добровольного изучения родных языков. Предыстория ситуации, которая назревала давно, такова. 20 июля 2017 г. по итогам заседания Совета по межнациональным отношениям в Йошкар-Оле Президент Российской Федерациии поручил Генеральной прокуратуре совместно с Рособрнадзором проверить соблюдение в субъектах Российской Федерации положений законодательства, касающихся обеспечения прав граждан на добровольное изучение родного языка из числа языков народов России и государственных языков республик Российской Федерации. В апреле 2018 г. в Госдуму был внесен законопроект о добровольном изучении национальных языков в школах республик Российской Федерации, согласно которому преподавание и изучение государственных языков республик Российской Федерации должно происходить на добровольной основе и не в ущерб преподаванию и изучению русского языка. Этот факт вызвал недовольство в республиках, что привело к созданию группы «За сохранение родных языков в обязательной части учебных планов общего образования» из представителей разных народов и республик Российской Федерации. Законопроект подвергся критике в национальных республиках, после этого последовала волна активной популяризации род- 
ных языков в форме праздников, олимпиад и т. д. В контексте обсуждаемой темы в тот период в СМИ превалировали такие, например, заголовки: «В Татарстане настаивают на возврате обязательного изучения татарского языка», «Курултай башкир попросил Госдуму не принимать закон о добровольном изучении национальных языков», «Чувашские активисты потребовали дать республикам право самим решать судьбу национальных языков» и т. д. Это свидетельствует об отрицательном настрое в регионах относительно решения данного вопроса. В республиках Российской Федерации отмечалась социальная напряженность по данному вопросу, имели место митинги, протесты в пользу обязательного изучения родных языков. Так, в Республике Калмыкия был проведен опрос среди разных социальных групп в июне 2018 г. (в период введения проекта постановления) и в апреле 2019 г. (ЛА БАН). В нем участвовало около 60 человек: представители интеллигенции, студенты, пенсионеры. Цель опроса - определить степень социального напряжения по языковому вопросу, выяснить, поддерживает ли население введение добровольного изучения языков в школе, удовлетворено ли оно действиями власти в этом вопросе, поддерживается ли уменьшение количества часов на родной язык в школе и т. д.

Как показал опрос, неудовлетворенных введением добровольного изучения языков среди населения Калмыкии оказалось в июне 2018 г. около $79 \%$ респондентов, участвовать в акциях протеста в республике сочли для себя возможным $64 \%$, исключили возможность протестов $27 \%$, затруднились ответить $9 \%$. Удовлетворенных опцией добровольного изучения родных языков оказалось всего 21 \% (ЛА БАН). Анализ публикаций СМИ того времени показал, что у населения возросли обеспокоенность сложившейся ситуацией, массовая тревога, недоверие руководству, попытки противостоять нежелательным изменениям. В этот период в республике зафиксировано проведение пикетов, митингов с требованием отменить указанный законопроект.

В 2018 г. наблюдался критический уровень социальной напряженности по вопросу добровольного изучения языка, обострение протестной деятельности, особенно в социальной группе интеллигенции, студентов. В 2019 г. отмечена некоторая стабилизация ситуации до уровня латентной социальной напряженности - неудовлетворенных введением добровольности изучения родных языков оказалось $56 \%$ респондентов, $31 \%$ сочли возможным участвовать в акциях протеста, 47 \% исключили возможность выступать в акциях протеста. Удовлетворенных возможностью добровольного изучения родных языков оказалось 44 \% (ЛА БАН). Отмечена нейтральная оценка ситуации, что не означает отсутствия проблемы, выявлена активность населения в форме устных письменных обращений в местные органы управления с пожеланиями и требованиями уладить ситуацию.

Дискурсивный анализ. Наряду с параметрическим и статистическим методами эффективным для прогнозирования дальнейшего развития языкового многообразия является дискурсивный метод. С помощью дискурс-анализа можно раскрыть структуры знаний и аргументации в определенном сообществе, а кроме того и аргументативные паттерны большого спектра акторов в дебатах о языках, то есть в дебатах как представителей власти, занимающихся вопросами языковой политики, так и представителей языковых общностей. Сначала опишем значение дискурс-анализа в области языковой политики в целом, затем приведем актуальные примеры реализации языковой политики Российской Федерации и покажем, как дискурсивный анализ может способствовать прогнозированию.

Дискурс-анализ в области языковой политики и языкового планирования основывается на их определении как социального процесса. Например, в работе Е. Баракос и Дж.В. Унгер, посвященной дискурсивным подходам к изучению языковой политики, показано, что для учета и анализа ее многочисленных уровней и воздействия ученому необходимо теоретически, методологически и эмпирически обращаться к политике с точки зрения структуры и агента, а это становится возможным благодаря применению различных форм критического дискурсивного анализа ситуаций языковой политики [Discursive Approaches..., 2016, p. 2]. Е. Баракос объеди- 
няет языковую политику с критическим дискурс-анализом: в модели языковой политики, которую анализирует исследователь, на первый план выдвигается дискурс как неотъемлемый ее компонент; она составлена, принята, интерпретирована, контекстуализирована и реконтекстуализирована в языке и посредством его [Barakos, 2012, p. 169]. Дискурсивный подход к языковой политике, по мнению Е. Баракос, предполагает, что она является частью деятельности по созданию смысла, которой руководит сеть социальных субъектов, действующих в определенных контекстах / времени / месте. Благодаря интеграции дискурса двойная функция языка как объекта языковой политики и средства ее конструирования или реконструирования может быть лучше проблематизирована [Barakos, 2016, p. 32].

Для чего нужны дискурсивные подходы к исследованию языковой политики? В отличие от подходов, базирующихся на классификации различных признаков языковых ситуаций, они позволяют лучше отразить динамику процессов в обществе и взаимодействия разных акторов. На базе исследования структур знаний и аргументации в определенном сообществе можно обнаружить области этноязыковой напряженности, выяснить, как дискурсивно реализуется роль (например, маргинализация) этноязыковых групп или конструируется единство и разнообразие в многоязычных государствах.

В качестве примера рассмотрим результаты исследования М. Вингендер (полностью они будут опубликованы в «Wiener Slawistischer Almanach» [Wingender]), которая, выявляя поля напряженности в языковой политике между федеральным центром Российской Федерации и Республикой Татарстан, показывает, как дискурс-анализ может быть продуктивно применен для изучения языковой политики в России. Объектом дискурсивного анализа послужили различные материалы: официальные - как федеративные, так и республиканские - документы, касающиеся языковой политики, и доступные онлайн-тексты СМИ, посвященные языковым проблемам. В центре внимания исследователя - тема поддержки vs. ограничения языкового многообразия. М. Вингендер установ- лен внушительный ряд официальных инструментов языковой политики (законы, программы, концепции), который показывает ее динамику. Дискурс-анализ этих документов раскрывает определенные аргументативные паттерны, реализованные со стороны как федеративного центра, так и Республики Татарстан. Дискурс-анализ текстов СМИ по языковым вопросам закрепляет или дополняет эти аргументативные паттерны.

Сравнительный анализ официальных документов федерального и республиканского уровней и текстов СМИ позволил описать дискурс как «пинг-понг» между федеральным центром и Республикой Татарстан, что реализуется:

- в дискурсивном событии, касающемся дву- или многоязычия;

- реакциях на федеральном и республиканском уровнях: законы и концепции;

- реакциях на федеральном и республиканском уровнях: дебаты в СМИ.

Детальный анализ дискурсов относительно их течения, дискурсивных событий и субдискурсов выявляет три кульминации в дебатах о языковой политике.

\section{языка.}

Кульминация I: Вопрос графики

Дискурсивное событие: Закон Республики Татарстан от 1999 г. о переходе татарского алфавита с кириллицы на латиницу.

Поскольку вопрос о графике татарского языка был прояснен на федеральном уровне в 2002 г. и кириллица была законодательно закреплена в качестве графической системы для татарского языка (дополнение к Закону «О языках народов Российской Федерации»), эта тема сегодня малоактуальна.

Кульминация II: Постепенное функциональное ограничение национальных языков.

Дискурсивное событие: Меры в системе образования, принятые начиная с 2007 года.

Примеры:

- Отмена национально-регионального компонента образования (2007 г.) и введение ЕГЭ.

Поддискурс: ущемление национальных языков.

- Новылй Федеральный закон об образовании (2012 г.). 
Поддискурс: равноправиенародов и языков.

- Предложения (2013 г.) о внесении поправок в Закон "О языках народов Российской Федерачии» (1991 г.) с требованием установления "русского как родного языка».

Поддискурс: существующее до сих пор ущемление русского vs. ущемление национальных языков.

- Закон Республики Татарстан о государственных языках (2013 г.) и новый закон Республики Татарстан об образовании (2013 2.).

Поддискурс: равноправие двух государственных языков Татарстана.

Кульминация III: Отмена обязательного преподавания государственных языков республик.

Дискурсивное событие: Концепции о преподавании русского языка.

Примеры:

- Проект концепиии Российской Федераиии о преподавании русского языка (2015 г.) и концепщия Российской Федерации о преподавании русского языка (2016 г.).

Поддискурс: обязательное преподавание национальных языков.

- Речь В.В. Путина в Йошкар-Оле на заседании президентского Совета по межнациональным отношениям в июле 2017 года.

Поддискурс: федеральные стандарты в системе образования vs. право на преподавание государственных / национальных языков.

- Федеральный законопроект о добровольном изучении начиональных языков, апрель 2018 г. (внесение изменений в Федеральный закон «Об образовании в Российской Федерации»).

Поддискурс: право на образование на родных языках и изучение национальных языков.

Охарактеризованный дискурс с его кульминационными моментами отражает динамику языковой политики в Российской Федерации относительно дебатов между федеральным центром и республиками.

Для повторяющихся аргументативных паттернов проведен дополнительный анализ топосов (о понимании топоса см.: [Wengeler, 2003]). При этом различаются следующие дискурсивные сообщества: сторонники укрепле- ния позиции татарского языка в Татарстане, сторонники укрепления позиции русского языка в Татарстане и сторонники укрепления позиции русского языка на федеральном уровне. Немаловажно, что эти позиции могут коррелировать с этнической принадлежностью акторов дискурса, но такая корреляция не абсолютна. Например, не все татары выступают за обязательное преподавание татарского языка и не все русские в Татарстане - против.

В качестве примера приведем только несколько топосов, каждый из которых упоминается отдельными дискурсивными сообществами.

Сторонники укрепления татарского языка в Татарстане:

- топос многонациональности: этническое и языковое многообразие как богатство; Россия как многонациональная страна;

- топос равноправия: равенство двух республиканских государственных языков (русского и татарского) в Татарстане.

Сторонники укрепления русского языка в Татарстане:

- топос пользы: социальная выгода русского языка; татарский как бесполезный язык; - экономический топос: русский язык как катализатор социального подъема.

Сторонники укрепления русского языка на федеральном уровне:

- топос единства: русский язык как скрепа для российской идентичности;

- топос приоритета: приоритет федерального государственного языка перед республиканскими государственными языками.

Что касается реализации топосов, то те из них, которые используются двумя или более дискурсивными сообществами, представляют особый интерес, поскольку наполняются различными аргументами. К таким топосам относятся следующие:

- топос безопасности: укрепление татарского языка и поощрение языкового многообразия как необходимое условие для предотвращения этноязыковых конфликтов в многонациональном государстве / сильная позиция русского языка и языковое единство, а также nation-building исключительно на основе русского языка как необходимые критерии для национальной безопасности и избежания этноязыковых конфликтов; 
- топос родного языка: сторонники укрепления татарского языка приводят как аргумент конституционное право на изучение и преподавание родного языка / сторонники укрепления русского языка в Татарстане требуют дать и русскому статус «родного»;

- топос ущерба: отмена обязательного преподавания татарского государственного языка в Татарстане вредит языковому разнообразию и угрожает татарскому языку / обязательное преподавание татарского государственного языка в Татарстане происходит в ущерб количеству часов преподавания русского языка и уровню его знания.

Подводя итог, отметим, что с начала 2000-х гг. существует напряженность между федеральным центром и республикой Татарстан в области языковой политики. Очевидно, что в последние годы произошло усиление мер со стороны федерального центра, особенно касательно добровольного преподавания республиканских государственных языков и национальных языков. Возможности действий республик в Российской Федерации относительно мер языковой политики все чаще ограничиваются.

После краткого анализа актуальной языковой политики в Российской Федерации и в завершение описания возможностей дискурсивного метода для изучения языковой политики обозначим перспективы его использования для социолингвистического прогнозирования:

- анализ динамики предшествующего развития языковой политики позволяет делать заключения о динамике последующего;

- выявление повторяющихся аргументативных паттернов дает возможность прогнозировать степень напряженности в языковой политике и возможности предотвращения напряженности;

- изучение дискурсивных механизмов языковой политики раскрывает многообразные факторы (идеологические, политические, экономические, социальные и др.) и таким образом делает возможным влияние на дальнейшее развитие языкового многообразия;

- исследование взаимодействия большого спектра акторов и их дискурсов позволяет «поставить диагноз» языковой политике и, опираясь на него, целенаправленно принять меры в будущем.

\section{Заключение}

Результаты исследования подтверждают, что прогнозирование языкового развития есть инструмент языковой политики и языкового планирования.

Социолингвистическое прогнозирование языковых процессов включает три основных этапа: 1) анализ сложившейся ситуации, 2) прогноз относительно ее развития, 3) опережающее отражение масштаба проблемы и разработка инструментов, которые влияют на развитие, например, с целью предотвращения и решения языковых конфликтов.

В статье рассмотрены лишь некоторые возможные методы языкового прогнозирования с опорой на современные языковые данные. Наиболее эффективным подходом является триангуляция методов исследования, которая подтверждает результаты комбинированных методик и при которой данные, полученные с применением одного метода верифицируют данные, извлеченные посредством других методов.

Лингвистическое прогнозирование необходимо рассматривать как инструмент языковой политики, способный помочь в улучшении языковой ситуации, укреплении национальных языков, что особенно важно для многонациональных стран, таких как Россия, которые в силу полиэтничности и многоязычия постоянно находятся в поисках правильного баланса: как сочетать целостность государства, языковую централизацию и потребность поликультурного населения страны в сохранении своих языков и культур.

Для того чтобы лингвопрогноз стал инструментом языкового планирования требуется, во-первых, высокая степень вовлеченности государственных структур и общественных организаций в сферу сохранения языков, языкового многообразия в целом, во-вторых, участие самих языковых общностей в процессе создания и культивации идеологем, способствующих формированию образа перспективного современного языка.

Сегодня необходимы разработка государственной целевой программы по сохранению и ревитализации языков России, сотрудничество с языковыми сообществами, учет их мнения при определении языковой полити- 
ки, важна опора на лингвистическую экспертизу и мнение языкового сообщества при рассмотрении вопроса о введении в образовательный стандарт обязательного изучения коренных языков, включая титульные языки республик, выработка законодательной инициативы о соблюдении языковых прав всех народов страны, пропаганда на государственном уровне идеи о культурном и психологическом преимуществе двуязычия (многоязычия) по сравнению с одноязычием, о том, что русский язык, знание которого необходимо всем гражданам Российской Федерации, должен усваиваться детьми не вместо этнического языка, а вместе с ним.

Таковы некоторые размышления о роли социолингвистического прогнозирования в вопросе сохранения баланса между языковым единством и языковым разнообразием в многонациональном государстве. Очевидно, что необходимо дальнейшее развитие методов данного прогнозирования, за которым в будущих работах последует разработка инструментов для рекомендаций.

\section{СПИСОК ЛИТЕРАТУРЫ}

Ахременко А. С., 2006. Политический анализ и прогнозирование. М. : Гардарики. 333 с.

Аюпова Л. Л., 1988. Вопросы социолингвистики: типы двуязычия в Башкирии. Свердловск : Изд-во Урал. ун-та. 69 с.

Баранова Г. В., Фролов В. А., 2012. Методология и методика измерения социальной напряженности // Социологические исследования. № 3 (335). С. 50-65.

Барановский Е. Г., Владиславлева Н. Н., 2002 . Методы анализа международных конфликтов. М. : Науч. кн. 240 c.

Биткеева А. Н., 2006. Калмыцкий язык в современном мире (социолингвистический аспект). М. : Наука. 364 c.

Биткеева А. Н., 2018. Развитие языков Российской Федерации: динамика, проблемы, прогнозы // Вопросы филологии. № 1 (61). С. 31-37.

Бородкин Л. И., 2016. Моделирование исторических процессов: от реконструкции реальности к анализу альтернатив. СПб. : Алетейя. $306 \mathrm{c}$.

Дырхеева Г. А., 2002. Бурятский язык в условиях двуязычия: проблемы функционирования и перспективы развития. Улан-Удэ : Изд-во Бурят. науч. центра СО РАН. 187 с.
Методы билингвистических исследований : сб. ст., 1976 / редкол.: А. Н. Баскаков, В. Ю. Михальченко. М. : [б. и.]. 130 с.

Михальченко В. Ю., 1984. Проблемы функционирования и взаимодействия литовского и русского языков. Вильнюс : Мокслас. 224 с.

Михальченко В. Ю., 2014. Языковой конфликт в полиэтническом государстве // Языковая политика и языковые конфликты в современном мире : докл. и сообщ. Междунар. конф. (г. Москва, 16-19 сент. 2014 г.) / отв. ред. А. Н. Биткеева, В. Ю. Михальченко. М. : [б. и.]. С. 209-213. URL: https://iling-ran.ru/library/sociolingva/ 2014_language_policy.pd.

Михальченко В. Ю., 2018. Национально-языковая политика и языковые конфликты // Пятнадцатый межвузовский семинар по лингвострановедению «Лингвострановедение: методы анализа, технология обучения» (г. Москва, 1415 июня 2017 г.): в 2 ч. Ч. 1. Языки в аспекте лингвострановедения: докл. и материалы. М. : МГИМО-Университет. С. 12-13.

Национальные языки в эпоху глобализации: Россия-Монголия, 2012 / отв. ред. А. Н. Биткеева, В. Ю. Михальченко. М. ; Улан-Батор : Тезауpyc. $464 \mathrm{c.}$

Никольский Л. Б., 1970. Прогнозирование и планирование языкового развития : докл. на VII Междунар. социол. конгр. (г. Варна, Болгария, 1970). М. : [б. и.]. 14 с.

Словарь социолингвистических терминов, 2006/ отв. ред. В. Ю. Михальченко; сост. : Т. Б. Крючкова [и др.]. М. : Ин-т языкознания РАН. 312 с.

Швейцер А. Д., 1977. Современная социолингвистика. Теория. Проблемы. Методы. М. : Наука. 176 с.

Язык и общество : энциклопедия, 2016. М. : Азбуковник. $872 \mathrm{c}$.

Языковая политика в контексте современных языковых процессов, 2016 / отв. ред. А. Н. Биткеева. М. : Азбуковник. $471 \mathrm{c}$.

Barakos E., 2012. Language policy and planning in urban professional settings: bilingualism in Cardiff businesses // Current Issues in Language Planning. Vol. 13, iss. 3. P. 167-186.

Barakos E., 2016. Language Policy and Critical Discourse Studies: Toward a Combined Approach // Discursive Approaches to Language Policy / E. Barakos, J. W. Unger (eds.). L. : Palgrave Macmillan. P. 23-49.

Discursive Approaches to Language Policy, 2016. E. Barakos, J. W. Unger (eds.). L. : Palgrave. 299 p.

Research Methods in Language Policy and Planning. A Practical Guide, 2015 / F. M. Hult, D. Cassels Johnson (eds.). Chichester, West Sussex : John Wiley \& Sons. 280 p. 
The Oxford Handbook of Language Policy and Planning, 2018 / J. W. Tollefson, M. Pérez-Milans (eds.). Oxford : Oxford University Press. 784 p.

The Routledge Handbook of Language and Politics, 2018 / R. Wodak, B. Forchtner (eds.). L. ; N.Y. : Routledge. $716 \mathrm{p}$.

Wengeler M., 2003. Topos und Diskurs. Begründung einer argumentationsanalytischen Methode und ihre Anwendung auf den Migrationsdiskurs (1960-1985). Tübingen : De Gruyter. 573 p.

Wingender M. Aktuelle Diskurse zu Sprachen und Sprachenpolitik in der Russischen Föderation (Debatten zwischen dem Föderationszentrum und der Republik Tatarstan) // Wiener Slawistischer Almanach / B. Brehmer, T. Reuther (eds.). Wien : [S. n.]. (In drucken).

\section{ИСТОЧНИКИ}

Данные Министерства науки и образования РФДанные Министерства науки и образования Российской Федерации. Медиа школа, 2016.

Закон Республики Мордовия - Закон Республики Мордовия от 06.05.1998 № 19-3 «О государственных языках в Республике Мордовия». URL: http://docs.cntd.ru/document/804950557.

Итоги Всероссийской переписи населения Итоги Всероссийской переписи населения 2010 года. В 11 т. Т. 4, кн. 1. М. : Статистика России, 2012. 847 с.

ЛА БАН - Личный архив А.Н. Биткеевой, 2018, 2019. Рос. кн. п. URL: www.bookchamber. ru/ statistics.html.

\section{REFERENCES}

Akhremenko A.S., 2006. Politicheskiy analiz $i$ prognozirovanie [Political Analysis and Forecasting]. Moscow, Gardariki Publ. 333 p.

Ayupova L.L., 1988. Voprosy sotsiolingvistiki: tipy dvuyazychiya $v$ Bashkirii [Issues of Sociolinguistics: Types of Bilingualism in Bashkiria]. Sverdlovsk, Izd-vo Uralskogo universiteta. $69 \mathrm{p}$.

Baranova G.V., Frolov V.A., 2012. Metodologiya i metodika izmereniya sotsialnoy napryazhennosti [Methodology and Measurement of Social Tensions]. Sociologicheskie issledovaniya [Sociological Studies], no. 3 (335), pp. 50-65.

Baranovskiy E.G., Vladislavleva N.N., 2002. Metody analiza mezhdunarodnykh konfliktov [Methods of Analysis of International Conflicts]. Moscow, Nauchnaya kniga Publ. 240 p.
Bitkeeva A.N., 2006. Kalmytskiy yazyk v sovremennom mire (sotsiolingvisticheskiy aspekt) [Kalmyk Language in the Modern World (Sociolinguistic Aspect)]. Moscow, Nauka Publ. 364 p.

Bitkeeva A.N., 2018. Razvitie yazykov Rossiyskoy Federatsii: dinamika, problemy, prognozy [Development of Languages of the Russian Federation: Dynamics, Problems, Forecasts]. Voprosy filologii, no. 1 (61), pp. 31-37.

Borodkin L.I., 2016. Modelirovanie istoricheskikh protsessov: ot rekonstruktsii realnosti $k$ analizu alternativ [Modeling of Historical Processes: From Reconstruction of Reality to Analysis of Alternatives]. Saint Petersburg, Aleteya Publ. 306 p.

Dyrkheeva G.A., 2012. Buryatskiy yazyk v usloviyakh dvuyazychiya: problemy funktsionirovaniya $i$ perspektivy razvitiya [Buryat Language in Bilingualism: Problems of Functioning and Prospects of Development]. Ulan-Ude, Izd-vo Buryatskogo nauchnogo tsentra SO RAN. $187 \mathrm{p}$.

BaskakovA.N., Mikhalchenko V.Yu., eds., 1976. Metody bilingvisticheskikh issledovaniy: sb. st. [Methods of Bilingual Studies. Collected Articles]. Moscow. 130 p.

Mikhalchenko V.Yu., 1984. Problemy funktsionirovaniya $i$ vzaimodeystviya litovskogo $i$ russkogo yazykov [Problems of Functioning and Interaction of the Lithuanian and Russian Languages]. Vilnius, Mokslas Publ. 224 p.

Mikhalchenko V.Yu., 2014. Yazykovoy konflikt v polietnicheskom gosudarstve [Language Conflict in Multiethnic Country]. Bitkeeva A.N., Mikhalchenko V.Yu., eds. Yazykovaya politika $i$ yazykovye konflikty $v$ sovremennom mire: dokl. i soobshch. Mezhdunar. konf. (g. Moskva, 16-19 sent. 2014 g.) [Language Policy and Language Conflicts in Contemporary World. Reports and Papers of the International Conference (Moscow, September 16-19, 2014)]. Moscow, pp. 209-213. URL: https://iling-ran.ru/ library/sociolingva/2014_language_policy.pd.

Mikhalchenko V.Yu., 2018. Natsionalno-yazykovaya politika i yazykovye konflikty [National Language Policy and Language Conflicts]. Pyatnadtsatyy mezhvuzovskiy seminar po lingvostranovedeniyu "Lingvostranovedenie: metody analiza, tekhnologiya obucheniya» (Moskva, 14-15 iyunya 2017 g.): v 2 ch. Ch. 1. Yazyki $v$ aspekte lingvostranovedeniya: dokl. $i$ materialy. [Fifteenth Interuniversity Seminar on Linguistics "Linguistics: Methods of Analysis, Teaching Technology (Moscow, June 14-15, 2017). In 2 parts. Part 1. Languages in the Aspect of Linguistic and Cultural Studies. Reports and 
Proceedings]. Moscow, MGIMO-Universitet, pp. 12-13.

Bitkeeva A.N., Mikhalchenko V.Yu., eds., 2012. Natsionalnye yazyki $v$ epokhu globalizatsii: Rossiya-Mongoliya [National Languages in the Era of Globalization: Russia-Mongolia]. Moscow, Ulan-Bator, Tezaurus Publ. 464 p.

Nikolskiy L.B., 1970. Prognozirovanie i planirovanie yazykovogo razvitiya: dokl. na VII Mezhdunar. sotsiolog. kongr. (g. Varna, Bolgariya, 1970) [Language Development Forecasting and Planning. Report at the $7^{\text {th }}$ International Sociological Congress (Varna, Bulgaria, 1970)]. Moscow. 14 p.

Mikhalchenko V.Yu., ed., 2006. Slovar sotsiolingvisticheskikh terminov [Dictionary of Sociolinguistic Terms]. Moscow, Institut yazykoznaniya RAN. 312 p.

Shveytser A.D., 1977. Sovremennaya sotsiolingvistika. Teoriya. Problemy. Metody [Modern Sociolinguistics. Theory. Problems. Methods]. Moscow, Nauka Publ. 176 p.

Yazyk i obshchestvo: entsiklopediya, 2016 [Language and Society: Encyclopedia]. Moscow, Azbukovnik Publ. 872 p.

Bitkeeva A.N., ed., 2016. Yazykovaya politika v kontekste sovremennykh yazykovykh protsessov [Language Policy in the Context of Modern Language Processes]. Moscow, Azbukovnik Publ. 471 p.

Barakos E., 2012. Language Policy and Planning in Urban Professional Settings: Bilingualism in Cardiff Businesses. Current Issues in Language Planning, vol. 13, iss. 3, pp. 167-186.

Barakos E., 2016. Language Policy and Critical Discourse Studies: Toward a Combined Approach. Barakos E., Unger, J.W., eds. Discursive Approaches to Language Policy. London, Palgrave, pp. 23-49.

Barakos E., Unger, J.W., eds., 2016. Discursive Approaches to Language Policy. London, Palgrave. 299 p.

Hult F.M., Cassels Johnson D., eds., 2015. Research Methods in Language Policy and Planning.
A Practical Guide. Chichester, West Sussex, John Wiley \& Sons. 280 p.

Tollefson J.W., Pérez-Milans M., eds., 2018. The Oxford Handbook of Language Policy and Planning. Oxford, Oxford University Press. 784 p.

Wodak R., Forchtner B., eds., 2018. The Routledge Handbook of Language and Politics. London, New York, Routledge. $716 \mathrm{p}$.

Wengeler M., 2003. Topos und Diskurs. Begründung einer argumentationsanalytischen Methode und ihre Anwendung auf den Migrationsdiskurs (1960-1985). Tübingen, De Gruyter. 573 p.

Wingender M., Aktuelle Diskurse zu Sprachen und Sprachenpolitik in der Russischen Föderation (Debatten zwischen dem Föderationszentrum und der Republik Tatarstan). Brehmer B., Reuther T., eds. Wiener Slawistischer Almanach, 83, Wien (accepted for printing).

\section{SOURCES}

Dannye Ministerstva nauki i obrazovaniya Rossiyskoy Federatsii [Data of the Ministry of Science and Education of the Russian Federation. Media shkola], 2016.

Zakon Respubliki Mordoviya ot 06.05.1998 № 19-Z «O gosudarstvennykh yazykakh $v$ Respublike Mordoviya» [Law of the Republic of Mordovia Dated May 6, 1998 no. 19-3 “On State Languages in the Republic of Mordovia"]. URL: http:// docs.cntd.ru/document/804950557.

Itogi Vserossiyskoy perepisi naseleniya 2010 goda. V11 t. T. 4, kn. 1 [Results of Population Census of 2010. In 11 Vols. Vol. 4, book 1]. Moscow, Statistika Rossii Publ., 2012.847 p.

Lichnyy arkhiv A.N. Bitkeevoy, 2018, 2019 [Personal Archive of A. N. Bitkeeva, 2018, 2019].

Rossiyskaya knizhnaya palata [Russian Book Chamber]. URL: www.bookchamber.ru/ statistics.html.

\section{Information about the Authors}

Aysa N. Bitkeeva, Doctor of Sciences (Philology), Professor, Leading Researcher, Institute of Linguistics of the Russian Academy of Sciences, Bolshoy Kislovskiy Lane, 1/1, 125009 Moscow, Russia; Head of the Department of Oriental Languages, Moscow State Pedagogical University, Prosp. Vernadskogo, 88, 119571 Moscow, Russia, aisa_bitkeeva@yahoo.com, https:/orcid.org/0000-0003-3765-2144

Monika Wingender, Doctor, Professor, Director, Giessen Center for Eastern European Studies, Justus Liebig University Giessen, Otto Behaghel Strasse, 10 D, 35394 Gissen, Germany, monika.wingender@slavistik.uni-giessen.de, https://orcid.org/0000-0002-9651-8693

Vida Yu. Mikhalchenko, Doctor of Sciences (Philology), Professor, Chief Researcher, Institute of Linguistics of the Russian Academy of Sciences, Bolshoy Kislovskiy Lane, 1/1, 125009 Moscow, Russia, vida-mi@mail.ru, https://orcid.org/0000-0002-0953-3466 
А.Н. Биткеева, М. Вингендер, В.Ю. Михальченко. Прогнозирование и языковое многообразие в РФ

\section{Информация об авторах}

Айса Николаевна Биткеева, доктор филологических наук, профессор, ведущий научный сотрудник, Институт языкознания РАН, пер. Б. Кисловский, 1/1, 125009 г. Москва, Россия; заведующая кафедрой восточных языков, Московский педагогический государственный университет, просп. Вернадского 88, 119571 г. Москва, Россия, aisa_bitkeeva@yahoo.com, https://orcid.org/0000-0003-3765-2144

Моника Вингендер, доктор, профессор, руководитель научного центра «Восточная Европа», Гиссенский университет им. Юстуса Либига, ул. Отто Бехагеля, 10 D, 35394 г. Гиссен, Германия, monika.wingender@slavistik.uni-giessen.de, https://orcid.org/0000-0002-9651-8693

Вида Юозовна Михальченко, доктор филологических наук, профессор, главный научный сотрудник, Институт языкознания РАН, пер. Б. Кисловский, 1/1, 125009 г. Москва, Россия, vida-mi@mail.ru,https://orcid.org/0000-0002-0953-3466 